\title{
Synthesis of polar copolymers by the process of emulsion via free radicals (FRP)
}

\author{
Síntesis de copolímeros polares por el proceso de emulsión a través de radicales libres \\ (FRP)
}

\author{
MAGAÑA-MALDONADO, Luis Mario $\dagger \&$ CONTRERAS-LÓPEZ, David*
}

Universidad de Guanajuato

ID $1^{\text {st }}$ Author: Luis Mario, Magaña-Maldonado / ORC ID: 0000-0001-9509-7631

ID 1 ${ }^{\text {st }}$ Coauthor: David, Contreras-López / ORC ID: 0000-0003-1384-4766, CVU CONACYT ID: 38297

DOI: $10.35429 / J Q S A .2019 .18 .6 .1 .5$

Received January 22, 2019; Accepted March 25, 2019

\begin{abstract}
At present, the polymer industry has gained increasing importance due to the versatility of its properties, as well as the impact they have on the environment. The present investigation provides the determination of optimal operating conditions for the polymerization of styrene and vinyl propionate in a Batch reactor, as well as the copolymerization of styrene with propionate monomers by the process of emulsion via free radicals, allowing to observe the variations with respect to Reaction yields and molecular weights. Another important factor is the activation of the initiator so that the polymerization process begins within each of the micelles. Likewise, it was found that, in the copolymerizations, there are considerable variations with respect to reaction yields and molecular weights as the concentrations are modified. In addition, it was found that there are higher yields in styrene polymerizations per solution than emulsion.
\end{abstract}

Styrene, Vinyl propionate, Free radicals

\begin{abstract}
Resumen
En la actualidad, la industria de los polímeros ha cobrado una creciente importancia debido a la versatilidad de sus propiedades, así como en el impacto que estos tienen con el ambiente. La presente investigación proporciona la determinación de condiciones de operación óptimas para la polimerización de estireno y de vinil propionato en un reactor Batch, así como la copolimerización de estireno con monómeros de propionato mediante el proceso de emulsión vía radicales libres, permitiendo observar las variaciones respecto a rendimientos de reacción y pesos moleculares. Otro factor importante es la activación del iniciador para que comience el proceso de polimerización dentro de cada una de las micelas. Así mismo, se encontró que, en las copolimerizaciones, hay variaciones considerables respecto a rendimientos de reacción y pesos moleculares en la medida que se modifican las concentraciones. A demás que se encontró que existen mayores rendimientos en polimerizaciones de estireno por solución que por emulsión esto debido principalmente a las técnicas de purificación utilizadas para cada caso.
\end{abstract}

Estireno, Vinil propionato, Radicales libres

Citation: MAGAÑA-MALDONADO, Luis Mario \& CONTRERAS-LÓPEZ, David. Synthesis of polar copolymers by the process of emulsion via free radicals (FRP). Journal of Quantitative and Statistical Analysis. 2019 6-18: 1-5

\footnotetext{
* Correspondence to Author (email: david.contreras@ugto.mx)

$\dagger$ Researcher contributing as first author.
} 


\section{Introduction}

Emulsion polymerization is widely used for the manufacture of several commercially important polymers. Many of these polymers are used as solid materials and must be isolated from the aqueous dispersion after polymerization. In other cases, the dispersion itself is the final product. A dispersion resulting from emulsion polymerization is often called latex. [1]

The latexes are used in a number of applications among which we can mention: adhesives, paints, paper and carpet coverings, fabric glues, printing inks, rubber products, cement reinforcement and in materials for immunodiagnostic tests. [2]

Emulsion polymerization is a type of radical polymerization involving a water-soluble initiator, a water-insoluble monomer and an emulsifier or surfactant (micelle-forming stabilizing agent). The main polymerization site is polymer particles (latex particles).

An emulsifier molecule (surfactant or emulsifier) consists of a long hydrophobic hydrocarbon chain with a hydrophilic end. By adding small amounts of emulsifier to the water, this is distributed between the aqueous phase where its molecules are individualized, and the interfaces of the system (adsorbed in the monomer droplets and / or in the polymer particles and / or in the liquid interface / gas). By increasing the amount of emulsifier its concentration in the water increases and above a certain value, the emulsifier molecules form aggregates called micelles. In them the hydrophobic group of the molecule is disposed oriented towards the interior and the hydrophilic group directed towards the aqueous phase.

The concentration of emulsifier to which micelles are formed corresponds to the saturation concentration of the emulsifier in water and is called critical micelle concentration (CMC). Its value depends on the nature of the emulsifier and the presence of electrolytes in the aqueous medium. By adding emulsifier over $\mathrm{CMC}$; the apparent solubility of the monomer increases because it can be absorbed in the hydrophobic interior of the micelles. [3]

The initiators used in the emulsion polymerizations are normally soluble in the aqueous phase.
At the moment when the initiator is added, it starts to decompose and starts to generate free radicals at a speed that depends on its nature, the temperature of the system and the $\mathrm{pH}$ of the medium. Because the initiator composition usually acidifies the medium, it is necessary to add a buffer substance or buffer. At moderate and high temperatures (> $50 \mathrm{C}$ ), dissociative initiators such as persulfates are used. On the other hand, at low temperatures ( -5 to 20 C) Redox-type initiators are used. [4]

In many industrial systems chain transfer agents (modifiers or regulators) are added which allow to control the molecular weight of the polymer chains produced throughout the reaction.

Monomers that are highly soluble in water or almost insoluble in water can not be polymerized by conventional conventional emulsion (in aqueous medium). In the case of soluble monomers, the polymerization in aqueous solution can occur simultaneously with the emulsion polymerization. [5]

\section{Methodology}

\section{Reagents}

Monomers: Styrene and Vinyl Propionate: with purity percentage> $98 \%$ (Sigma-Aldrich) Washing: 0.1M Sodium Hydroxide

Distillation: Vinyl Propionate $96{ }^{0} \mathrm{C}$

Surfactant: Sodium Dodecyl Sulfate (SDS). Initiator: Benzoyl Peroxide and Potassium Persulfate: with a purity percentage of $97 \%$ (Sigma-Aldrich)

Solvent: Distilled water, methyl ethyl ketone (MEK) and Toluene.

Purification: 96\% methanol and distilled wáter.

\section{Polymerization of styrene by emulsion}

The emulsion polymerization process was followed via FRP. The reaction was carried out in a $250 \mathrm{ml}$ Batch reactor, using for the aqueous phase a constant volume of $150 \mathrm{ml}$ of distilled water, with a concentration of Dodecyl Sulfate of $33.3 \mathrm{~g} / \mathrm{L}$, while for the dispersed phase a 20 $\mathrm{ml}$ volume of Styrene with $0.350 \mathrm{~g}$ of initiator (KPS). The synthesis was carried out at a stirring speed of $500 \mathrm{rpm}$ at a temperature of $60 \pm 2{ }^{\circ} \mathrm{C}$ for 3 hours. 


\section{Polymerization of styrene by solution}

The polymerization process was followed by solution via FRP. The reaction was carried out in a $250 \mathrm{ml}$ Batch reactor, using for the aqueous phase a volume of $150 \mathrm{ml}$ of Toluene, while for the dispersed phase a volume of $20 \mathrm{ml}$ of Styrene with $0.350 \mathrm{~g}$ of initiator (BPO) was added. The synthesis was carried out at a stirring speed of $500 \mathrm{rpm}$ at a temperature of $60 \pm 2^{\circ} \mathrm{C}$ for 3 hours.

\section{Polymerization of Vinyl Propionate by solution}

The polymerization process was followed by solution via FRP. The reaction was carried out in a $250 \mathrm{ml}$ Batch reactor, using for the aqueous phase a volume of $150 \mathrm{ml}$ of MEK, while for the dispersed phase a volume of $20 \mathrm{ml}$ of Vinyl Propionate was added with $0.350 \mathrm{~g}$ of initiator ( $\mathrm{BPO})$. The synthesis was carried out at a stirring speed of $500 \mathrm{rpm}$ at a temperature of $60 \pm 2^{\circ} \mathrm{C}$ for 3 hours.

\section{Polymerization of Vinyl Propionate by emulsion}

The emulsion polymerization process was followed via FRP. The reaction was carried out in a $250 \mathrm{ml}$ Batch reactor, using for the aqueous phase a volume of $150 \mathrm{ml}$ of distilled water, with a concentration of

In the article content any graphic, table and figure should be editable formats that can change size, type and number of letter, for the purposes of edition, these must be high quality, not pixelated and should be noticeable even reducing image scale.

\section{Copolymerization of Styrene-Vinyl Propionate}

The polymerization process was followed by solution and by emulsion via FRP. The reaction was carried out in a $250 \mathrm{ml}$ Batch reactor, using $150 \mathrm{ml}$ of MEK for the solution case and $150 \mathrm{ml}$ of distilled water, with a concentration of Dodecyl Sulfate of $33.3 \mathrm{~g} / \mathrm{L}$ for the aqueous phase, while for the Dispersed phase was added a monomer mixture for both emulsion and solution; $15 \mathrm{ml}$ of styrene with three variations of vinyl propionate in each reaction; $2: 1,4: 1,1$ : 1 percentage by weight with respect to styrene, adding to the BPO and KPS system for each case: $350 \mathrm{~g}$, at $\mathrm{T}: 60^{\circ} \mathrm{C}$.
The synthesis was carried out at a stirring speed of $500 \mathrm{rpm}$ for 3 hours.

\section{Polymer purification}

For the polymers by emulsion, $0.5 \mathrm{~g}$ of Sodium Chloride is added, it is dissolved in the sample. The liquid is decanted to evaporate. Then add 10 $\mathrm{ml}$ of Toluene to dissolve and finally methanol is added at a ratio of $1: 1.5$, decanting leaving the solid to dry at $40{ }^{\circ} \mathrm{C}$.

For the polymers per solution, only wash with $80 \mathrm{ml}$ of cold methanol to remove the solvent and let it dry at $40{ }^{\circ} \mathrm{C}$.

\section{Results}

\begin{tabular}{|c|c|c|c|}
\hline Reaction & $\begin{array}{l}\text { Relationship } \\
\text { MOL S-PV }\end{array}$ & Terms & \% Solids \\
\hline $\begin{array}{l}\text { RXN } 2 \\
\text { Solutión }\end{array}$ & PV & $\begin{array}{l}500 \mathrm{rpm}, \quad 60^{\circ} \mathrm{C}, \\
0.35 \mathrm{~g} \mathrm{BPO}, 150 \\
\text { ml MEK }\end{array}$ & $13 \%$ \\
\hline $\begin{array}{l}\text { RXN } 10 \\
\text { Solutión }\end{array}$ & $\mathrm{S}$ & $\begin{array}{l}500 \mathrm{rpm}, 60^{\circ} \mathrm{C}, \\
0.35 \mathrm{~g} \mathrm{BPO}, 150 \\
\text { ml Tolueno }\end{array}$ & $12 \%$ \\
\hline $\begin{array}{l}\text { RXN } 4 \\
\text { Solutión }\end{array}$ & $4: 1$ & $\begin{array}{l}500 \mathrm{rpm}, 60^{\circ} \mathrm{C}, \\
0.35 \mathrm{~g} \mathrm{BPO}, 150 \\
\text { ml MEK }\end{array}$ & $12 \%$ \\
\hline $\begin{array}{l}\text { RXN } 3 \\
\text { Solutión }\end{array}$ & $2: 1$ & $\begin{array}{l}500 \mathrm{rpm}, 60^{\circ} \mathrm{C}, \\
0.35 \mathrm{~g} \mathrm{BPO}, 150 \\
\text { ml MEK }\end{array}$ & $14 \%$ \\
\hline $\begin{array}{l}\text { RXN } 5 \\
\text { Solutión }\end{array}$ & $1: 1$ & $\begin{array}{l}500 \mathrm{rpm}, \quad 60^{\circ} \mathrm{C}, \\
0.35 \mathrm{~g} \mathrm{BPO}, 150 \\
\mathrm{ml} \mathrm{MEK}\end{array}$ & $18 \%$ \\
\hline
\end{tabular}

Table 1 Operating conditions for reactions in solution (SStyrene, PV-Vinyl Propionate) of Figure 2

\begin{tabular}{|c|c|c|c|}
\hline Reaction & $\begin{array}{l}\text { Relationship } \\
\text { MOL S-PV }\end{array}$ & Terms & \%Solids \\
\hline $\begin{array}{l}\text { RXN } 8 \\
\text { Emulsión }\end{array}$ & $4: 1$ & $\begin{array}{l}500 \mathrm{rpm}, \quad 60^{\circ} \mathrm{C}, \\
0.35 \mathrm{~g} \mathrm{KPS}, \quad 150 \\
\text { ml H20-D, } 5 \mathrm{~g} \\
\text { SDS }\end{array}$ & $10 \%$ \\
\hline $\begin{array}{l}\text { RXN } 7 \\
\text { Emulsión }\end{array}$ & $2: 1$ & $\begin{array}{l}500 \mathrm{rpm}, \quad 60^{\circ} \mathrm{C}, \\
0.35 \mathrm{~g} \text { KPS, } 150 \\
\mathrm{ml} \mathrm{H} 20-\mathrm{D}, \quad 5 \mathrm{~g} \\
\text { SDS }\end{array}$ & $11 \%$ \\
\hline $\begin{array}{l}\text { RXN } 3 \\
\text { Emulsión }\end{array}$ & $1: 1$ & $\begin{array}{l}500 \mathrm{rpm}, \quad 60^{\circ} \mathrm{C}, \\
0.35 \mathrm{~g} \text { KPS, } 150 \\
\text { ml H20-D, } 5 \mathrm{~g} \\
\text { SDS }\end{array}$ & $15 \%$ \\
\hline $\begin{array}{l}\text { RXN 1 } \\
\text { Emulsión }\end{array}$ & S & $\begin{array}{l}500 \mathrm{rpm}, \quad 60^{\circ} \mathrm{C}, \\
0.35 \mathrm{~g} \text { KPS, } 150 \\
\text { ml H20-D, } 5 \mathrm{~g} \\
\text { SDS }\end{array}$ & $10 \%$ \\
\hline $\begin{array}{l}\text { RXN } 6 \\
\text { Emulsión }\end{array}$ & PV & $\begin{array}{l}500 \mathrm{rpm}, \quad 60^{\circ} \mathrm{C}, \\
0.35 \mathrm{~g} \mathrm{KPS0}, 150 \\
\mathrm{ml} \mathrm{H} 20-\mathrm{D}, \quad 5 \mathrm{~g} \\
\text { SDS }\end{array}$ & $11 \%$ \\
\hline
\end{tabular}

Table 2 Operating conditions for reactions in emulsion (SStyrene, PV-Vinyl Propionate) of Figure 2 
In the experiment, 10 reactions were performed, which involved different volumes of Vinyl Propionate and Styrene according to molar ratios. The operating conditions to analyze or the effects on the polymerization were kept constant.

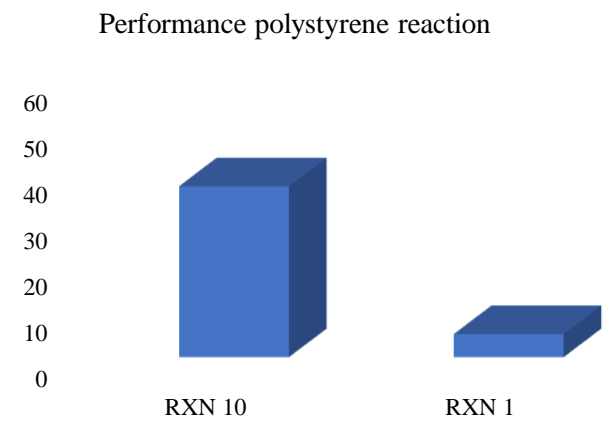

Figure 1 Performance graph of the polystyrene reaction, (RXN 10 per solution, RXN 1 emulsion)

In reactions where only styrene was used as a monomer, higher yields were obtained for solution polymerization than emulsion as shown in Figure 1, mainly because the solvent can affect the polymerized product in addition to the emulsion purification method is a little more rigorous, which reduces performance considerably

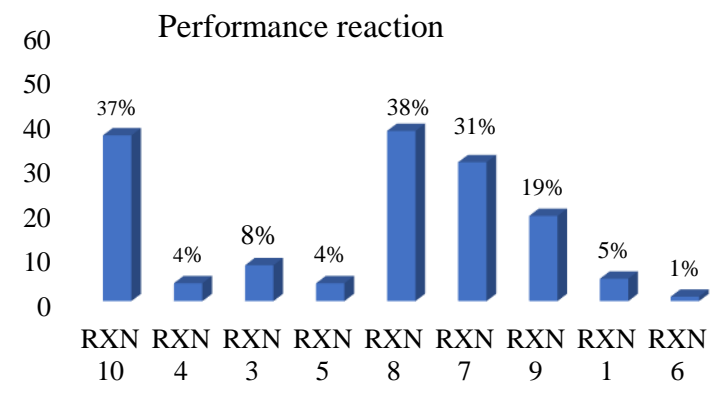

Figure 2 Performance graph of reactions by solution and emulsion

We see in figure 2 that the highest yields obtained are in the reactions where it involves the highest percentage in mol of styrene, except for the rxn 1 by emulsion since, because it is slightly soluble in water, so it tends to be lost the greater percentage in monomer solids during purification.

It is clear that, in emulsion copolymerizations, the yields decrease with the increase in vinyl monomer.

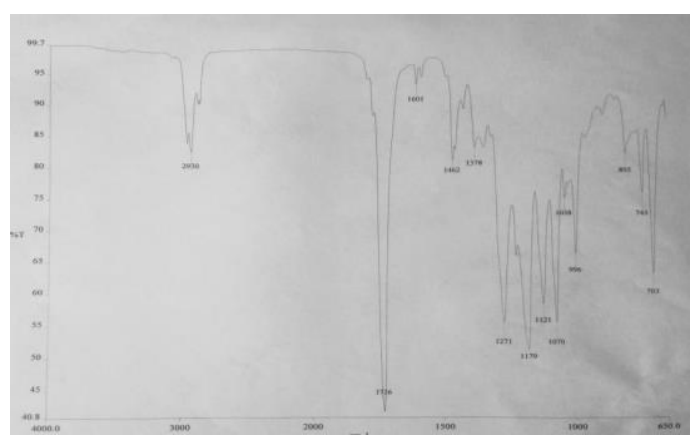

Figure 3 Infrared Spectrum of Vinyl Propionate per solution

Figure 3 shows the IR spectrum for the rxn 2, which is polymerized vinyl propionate, we can see the presence of some functional groups such as the methyl group in the signal of 2930, which confirms the signal of 1400 the presence of a $\mathrm{CH}$ group, as well as the presence of a $\mathrm{C}=$ $\mathrm{O}$ group in the 1726 signal, which belongs to an aldehyde confirmed by the signals between 1200 and 1000. The 700 signal indicates the presence of a propyl group. Therefore, the polymerization carried out can be checked.

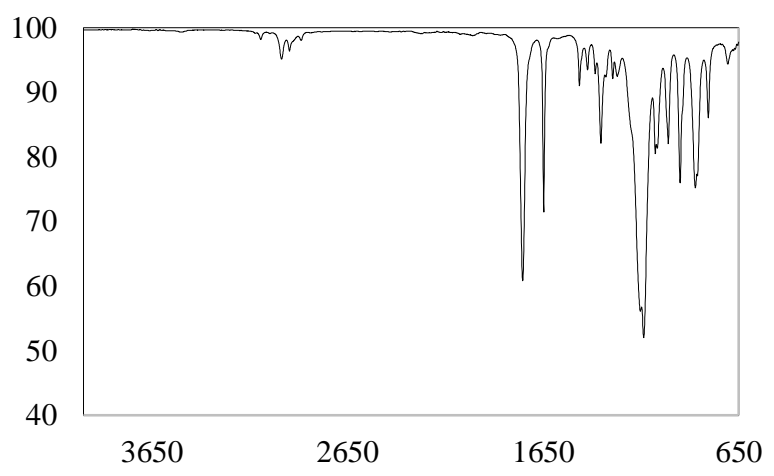

Figure 4 Infrared Spectrum of Distilled Monomer Vinyl Propionate

In Figure 4 it is possible to reaffirm the purification of the Vinyl monomer, achieving the elimination of its inhibitors, of which hydroquinones were mainly found as inhibitors. Therefore, no signal of any cyclic compound is seen in the spectrum.

\begin{tabular}{|l|r|r|}
\hline Reactión & \multicolumn{1}{c}{$\begin{array}{c}\text { Mlecular Weight } \\
\mathrm{kg} / \mathrm{mol}(\mathrm{Mv})\end{array}$} & $\begin{array}{c}\text { Mlecular Weight } \\
\mathrm{kg} / \mathrm{mol}(\mathrm{MW})\end{array}$ \\
\hline RXN 10 & 2,582 & $3,098.9$ \\
\hline RXN 4 & 978.6 & $1,174.4$ \\
\hline RXN 3 & 256.7 & 308.1 \\
\hline RXN 5 & 2,520 & $3,024.1$ \\
\hline
\end{tabular}

Table 3 Comparative table of average molecular weights in weight by viscosimetry (at $25^{\circ} \mathrm{C}$ ) 
In table 2 it can be seen that a higher molecular weight was obtained for the reaction by solution where it only involves styrene, in the copolymerizations, with the percentage increase in monomer solids, the molecular weight decreases, at the moment they are equalized the molar quantities, the molecular weights increase.

\section{Conclusions}

It is important to mention that by emulsion, low conversions were obtained for the useful life of the initiator. This determines the initiation and propagation of the reaction since its function is to generate free radicals and, therefore, limits the conversion.

It was possible to synthesize copolymers by emulsion with higher yields with the decrease of concentrations of vinyl monomer. Furthermore, it is important to ensure the formation of an adequate micellar concentration to guarantee the appropriate reaction medium.

Finally, it could be noted that the yields of the styrene polymerizations are higher by solution polymerization than by emulsion, due to the type of purification that must be carried out for each of the different techniques

\section{References}

[1] Anderson D. (2000) Emulsion Polymerisation and applications of latex. Akron University. Ohio.

[2] Mendizabal. M. E. (2016). Emulsiones, microemulsiones obtenidas mediante polimerización de monómeros. Universidad de Guadalajara. Guadalajara

[3] Odian, G. (1991). Principles of Polymerization 3rd Ed., John Wiley and Sons, Inc., New York.

[4] L.M. Gungliotta (2015). Polimerizacion de monómeros solubles en agua. Universidad Nacional del Litoral. Argentina.

[5] L. M. Gungliotta. (2013). Polimerizaciones Radicalarias Heterogéneas. Universidad Nacional del Litoral. Argentina. 